\title{
Stress Eesilience in Special Operations - Simulation-based Counter-terrorism Training from a Communication Perspective
}

\author{
P. Merkt (Philipp Merkt)ำ, S. Wilk Vollmann (Sophia Wilk-Vollmann)², V. Krcmery \\ (Vladimir Krcmery) ${ }^{3,4}$
}

${ }^{1}$ Carl Remigius Medical School Universitiy Fresenius, Idstein, DE.

${ }^{2}$ Bundeswehrkrankenhaus Berlin - Clinic X, Anaesthesiology, Intensive

Care Medicine, Pain Therapy and Emergency Mediciner, Berlin, DE.

${ }^{3}$ St. Elizabeth University of Health and Social Work, Bratislava, SK.

${ }^{4}$ Slovak Med Univ Trop Inst Bratislava, SK and Nairobi, KE.

\section{E-mail address:}

notfallmedizin@carl-remigius.de

\section{Reprint address:}

Philipp Merkt

Carl Remigius Medical School Universitiy Fresenius

Limburger Str. 2

65510 Idstein

Germany

Source: Clinical Social Work and Health Intervention

Volume: 12

Issue: 3

Pages: $93-96$

Cited references: 8

\section{Reviewers:}

Selvaraj Subramanian

Kuala Lumpur, KL

Claus Muss

Zurich, $\mathrm{CH}$

\section{Keywords:}

Stress. Resilience.

\section{Publisher:}

International Society of Applied Preventive Medicine i-gap

CSWHI 2021; 12(3): 93 - 96; DOI: 10.22359/cswhi_12_3_16 C Clinical Social Work and Health Intervention

\section{Abstract:}

Master students of the part-time study program in the winter semester 2020/21 Crisis \& Emergency Management successfully complete the study module Operational Medicine $18 \mathrm{~F}$ for the first time. Furthermore, participants from the professional groups of the health service, aid organizations, specialized police forces, the German Armed Forces as well as mission and outreach workers were represented in South Germany. 


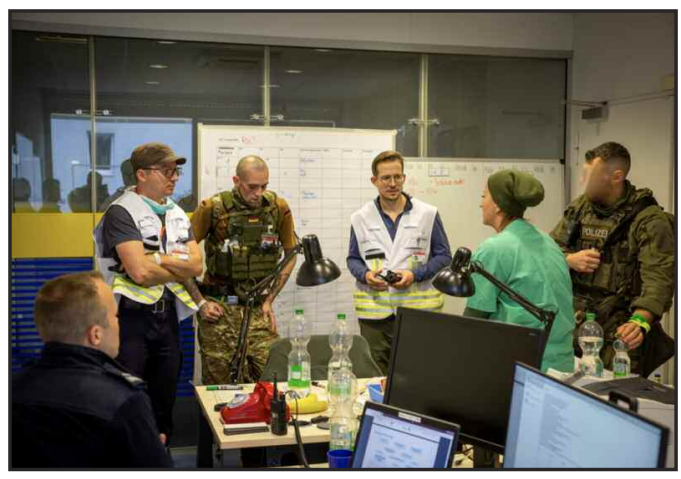

Figure 1: Interdisciplinary work by medics, firefighters, police and military.

Photo HS- Fresenius

\section{Introduction}

The advanced training and the study module: "Emergency Medicine - Survival - Tactics - 18F" is focused towards people with prior medical knowledge as first responders up to emergency doctors to prepare them for missions in possible potentially dangerous situations. Within the compact 3.5-day course/study module at the Fresenius University of Applied Sciences, Idstein Germany, participants and students are prepared through training and interdisciplinary instruc-

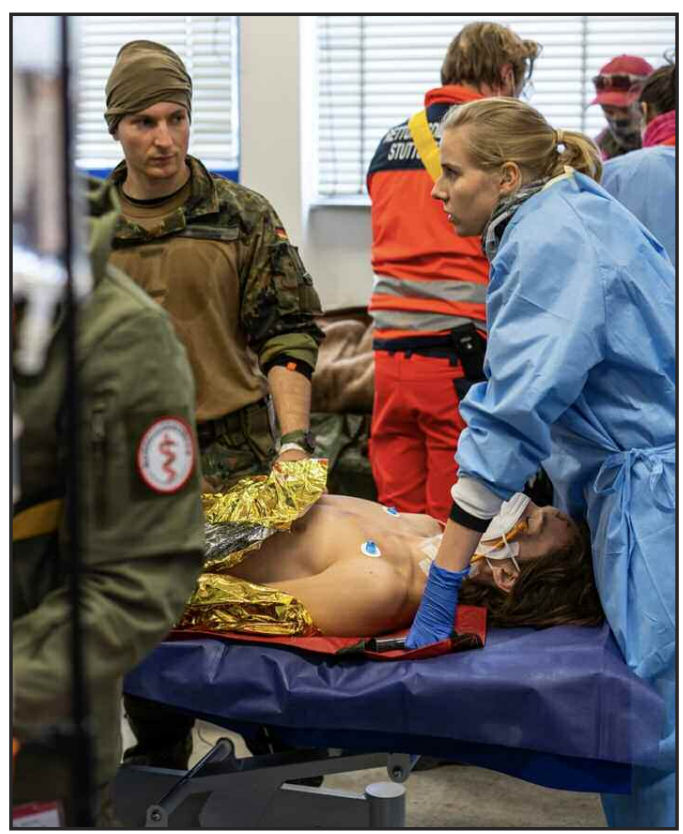

Figure 2: Field medical first aid is only possible together. tional discussions to be able to handle emergency situations in compliance with tactical and medical principles during the course as well as on the job.

In 3.5 days, stress resilience is constantly researched in relation to the course/study module in special operational situations, as well as specifically addressed in teaching. The term resilience is described from the Latin "resilire" as bouncing back or rebounding. This describes resilience in its dimensions: physical willpower; vital constitution; adaptability; self-preservation. The dimensions mentioned are hormonally balanced in the human body and regulated according to the situation (Selye, H. 1950). This observation is done by means of questionnaires to participants in the study. Vital parameters are recorded via a 72 hour live heart rate measurement and venous blood gas analysis. Exercise parameters: Cortisol,

a-amylase and testosterone are obtained from saliva samples taken from the participants (Merkt Ph., 2019). These are processed in the laboratory using apparatus diagnostics and measured using ELISA (enzyme-linked immunosorbent assay). The adaptation reactions are divided into 7 categories (Stadelman J., 1998). These categories are instrumentally determined by cognition in complex situations, decision-making and acting under stress. In the $18 \mathrm{~F}$ course, these areas of exploration are observed in an interdisciplinary manner on the individual persons as well as recorded and evaluated in an intergroup comparison.

Group integration in special situations - using the example of the study module Emergency Medicine $18 \mathrm{~F}$, including narrative cooperation, comradeship, loyalty and pride. The identification of the job profile as well as the reputation within the occupational field, respectively the specialization (health: specialist \& nurse/medical doctor; rescue service; emergency paramedic; paramedic;, fire brigade; machinist; weapon bearer police; personal protection Bundeswehr, etc.), also belong to these points:

1. Physical fitness, people who are physically fit, have a balanced diet and sleep are better able to cope with prolonged stress. Age and gender also play a role. In the research project of the Division of Emergency Medicine, this is measured at the beginning of the course with an initial measurement (1), rowing ergometry (2) 
and based on the scenario (3) during the course.

2. Basic and advanced training, superior skills as well as absolutely safe mastery of weapons, rescue equipment and handling procedures. The contents of the 3.5 days on: command and control; staff work; rescue and extrication under enemy fire (CUF); advanced care of patients with blast, burn and gunshot injuries as well as the handling of scarce resources increase the operational success in special situations.

3. Hope and faith, conviction (patriotism, religion, prayer) as well as identity with the "vocation" represent a central focus. The time and place factor are also important, which should be foreseeable within the mission/assignment. Due to the simulation, the participants are exposed to a fictitious situation in Kyrgyzstan. This fictitious mission simulation is continuously underpinned by role-players. In addition, the 72-hour course teaches the psychosocial stresses of an individual and the group.

4. Own personality, self-esteem, confidence, humor, independence, loyalty, will to persevere and robustness in direct relation to resilience, as well as courage. Questionnaires based on an initial measurement (1), the rowing ergometry (2) and in the course of the scenario (3).

5. leadership / people in leadership responsibility, most course participants have a need for leadership. Good supervisors with leadership responsibility care about the group / departmen-

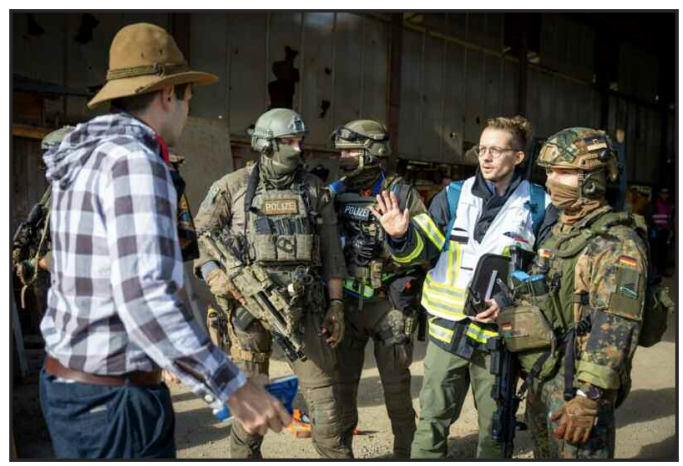

Figure 3: Conciliation \& de-escalation as well as planning far ahead is the life insurance of every emergency worker.

Source Photo: HS- Fresenius tal interests, but are also able to enforce their will with coercion or similar measures if necessary. The leadership processes were controlled by stress-driven miscommunication and factual information gaps over the radio. These were recorded and transcribed according to their emotional character.

6. Trust, is presented as a superordinate variable. The more positive the individual scores in the first six categories, the more likely it can be assumed that this superordinate variable is growing in general "subjective feeling".

\section{Conclusion}

Communication in prehospital patient care has so far played a subordinate role in the training of medical and non-medical staff. Yet it has a significant influence on patient care processes and patient safety. Incidents that have occurred due to miscommunication could be avoided in almost $30 \%$ of cases if effective countermeasures were taken (Wilk-Vollmann S, Siegl L, Siegl K, Hohenstein C ., 2018). In particular, the interaction between medical and non-medical staff shows deficits. In particular, unclear and stressful workflows with a risk to their own safety, as presented in the course Emergency Medicine - Survival - Tactics (Emergency Medicine - Survival - Tactics) (Merkt Ph., Wolz C., Gasmück J. (2018), pose a risk for incidents.

Patient safety can be increased and incidents minimized by means of uniform training concepts and established care schemes. In view of the current threat situation, this also includes the training of civilian rescue service participants in the basic principles of tactical medicine. Team and communication training should already be implemented in the training phase and the knowledge should be regularly refreshed in practical application. Debriefings should be part of everyday work and not only used in special cases. The routine that develops with this procedure helps to address critical situations and find solutions in case of serious incidents or disagreements in the team, but also to strengthen resilience in the team.

\section{References}

1. JURG S (1998) Selected Aspects of Military Psychology: Leading under Stress, Stuttgart, Wien Huber Verlag, 1998 pp.55-66. 
2. HELLWELL S, CERNAK I (2018) Measuring Resilience to Operational Stress in Canadian Armed Forces Personnel. Journal of Traumatic Stress DOI 10.1002/jts. Journal of Traumatic Stress February 2018, 31, pp. 8910.

3. RALL M, GABA DM (2009) Human performance and patient safety. In: Miller RD (ed.) Miller's Anesthesia. Elsevier Churchhill Livingstone, Philadelphia, pp 93-150.

4. SELYE H (1950) Stress and the General Adaptation Syndrome. British Medical Journal 1: 1383-1392. https://doi.org/10.1136/ bmj.1.4667.1383.

5. MERKT P, WOLZ CH, GASMUCK J (2018) Evaluation of the Carl Remigius Medical School course "Tactical Emergency Medicine 18F": a prospective study to investigate learning curves in tactical emergency medicine. Idstein.

6. MERKT PH, SAVELSBERGH A (2020) $R e$ silience research: A prospective study to investigate stress resilience in special operations situations at the Tactical Emergency Medicine 18F course using ELISA-assisted cortisol and $\alpha$-amylase measurement. Unpublished doctoral thesis. University of Witten-Herdecke, 2020.

7. WILK-VOLLMANN S, SIEGL L, SIEGL K, HOHENSTEIN C (2018) Miscommunication as a risk focus in patient safety. Der Anaesthesist 67 (4): 255-263. doi:10.1007/s00101018-0413-x.

8. MERKT PH, HOFMANN S, WEITEMEYER D, (2018) Course description for the course Tactical Emergency Medicine Survival - Tactics $18 F$. Fresenius University of Applied Sciences Idstein 2018. 